\title{
Assessing the performance of a plastic optical fibre turbidity sensor for measuring post-fire erosion from plot to catchment scale
}

\author{
J. J. Keizer ${ }^{1}$, M. A. S. Martins ${ }^{1}$, S. A. Prats ${ }^{1}$, L. F. Santos ${ }^{1}$, D. C. S. Vieira ${ }^{1}$, R. Nogueira ${ }^{2}$, and L. Bilro ${ }^{2}$ \\ ${ }^{1}$ Earth surface processes team, Centre for Environmental and Marine Studies (CESAM), \\ Dept. Environment and Planning, University of Aveiro, Campus Universitário de Santiago, \\ 3810-193 Aveiro, Portugal \\ ${ }^{2}$ Instituto de Telecomunicações, Aveiro (IT-Aveiro), Campus Universitário de Santiago, \\ 3810-193 Aveiro, Portugal
}

Correspondence to: J. J. Keizer (jjkeizer@ua.pt)

Received: 13 April 2015 - Published in SOIL Discuss.: 11 May 2015

Accepted: 1 September 2015 - Published: 24 September 2015

\begin{abstract}
This study is the first comprehensive testing of a novel plastic optical fibre turbidity sensor with runoff samples collected in the field and, more specifically, with a total of 158 streamflow samples and 925 overland flow samples from a recently burnt forest area in north-central Portugal, collected mainly during the first year after the wildfire, as well as with 56 overland flow samples from a nearby long-unburnt study site. Sediment concentrations differed less between overland flow and streamflow samples than between study sites and, at one study site, between plots with and without effective erosion mitigation treatments. Maximum concentrations ranged from 0.91 to $8.19 \mathrm{~g} \mathrm{~L}^{-1}$ for the micro-plot overland flow samples from the six burnt sites, from 1.74 to $8.99 \mathrm{~g} \mathrm{~L}^{-1}$ for the slope-scale overland flow samples from these same sites, and amounted to $4.55 \mathrm{~g} \mathrm{~L}^{-1}$ for the streamflow samples. Power functions provided (reasonably) good fits to the - expected - relationships of increasing normalized light loss with increasing sediment concentrations for the different sample types from individual study sites. The corresponding adjusted $R^{2}$ values ranged from 0.64 to 0.81 in the case of the microplot samples from the six burnt sites, from 0.72 to 0.89 in the case of the slope-scale samples from these same sites, and was 0.85 in the case of the streamflow samples. While the overall performance of the sensor was thus rather satisfactory, the results pointed to the need for scale of site-specific calibrations to maximize the reliability of the predictions of sediment concentration by the POF (plastic optical fibre) sensor. This especially applied to the cases in which sediment concentrations were comparatively low, for example following mulching with forest residues.
\end{abstract}

1

Wildfires are now widely recognized as a potential driver of conspicuous changes in geo-morphological and hydrological processes, through their direct effects on vegetation, litter layer and topsoil (Shakesby, 2011; Moody et al., 2013). Studies across the globe have shown strong and sometimes extreme responses in runoff and erosion in recently burnt areas, especially during the earlier stages of the so-called "window of disturbance" (e.g. Cerdà, 1998; Lane et al., 2006; Ro- bichaud et al., 2007). Nonetheless, important research gaps remain with respect to wildfire impacts on runoff and especially soil erosion, in part due to the relatively limited number of post-fire erosion studies as compared to erosion studies in agricultural areas (Shakesby, 2011). The latter is wellillustrated by the four studies that appear to have been carried out in the Mediterranean Basin on sediment yields from recently burnt catchments (Lavabre and Martin, 1997; Inbar et al., 1998; Mayor et al., 2007; Keizer et al., 2015). Clearly, more studies have been published on post-fire erosion at the 
plot-to-slope scale in the Mediterranean Basin (e.g. Thomas et al., 1999; Fernández et al., 2007; Prats et al., 2014). However, they have typically addressed soil losses with a relatively coarse temporal resolution, i.e. multiple runoff events, which is hampering further insight in underlying sediment transport processes.

The advantages of employing turbidity sensors in erosion studies has been increasingly recognized since their introduction more than 2 decades ago (Downing, 2006). Nonetheless, commercially available turbidity sensors such as the OBS$3+$ Suspended Solids and Turbidity Monitor $\left({ }^{\odot}\right.$ Campbell) typically require complex installations, extensive calibration to local conditions, and, perhaps most importantly, considerable financial resources for their purchase. Fibre optical turbidity sensors and, in particular, those using plastic optical fibres (POFs) are now widely viewed to offer various important advantages over traditional methods of sensing (Zienmann et al., 2008). POF sensors are not only comparatively inexpensive but also easy to handle, immune to electromagnetic interferences, and can easily be used in multi-sensor schemes (Yeo et al., 2008). This would, amongst other advantages, allow for continuous in situ recording of sediment concentrations in plot-scale studies and to reduce substantially laboratory efforts by substituting standard methods for at least a large part of the runoff samples.

Over the past decade, various authors (Ruhl et al., 2001; Campbell et al., 2005; Postolache et al., 2007) have obtained promising results in measuring turbidity of aqueous solutions with POF sensors. Nonetheless, in their review study, Omar and MatJafri (2009) identified the need for more extensive testing, in particular also with respect to the dependence on particle size. Therefore, this study aimed at further testing the performance of the POF sensor developed by Bilro et al. (2010), which had provided promising results for contrasting suspended materials, including ashes from recently burnt areas (Bilro et al., 2011). More specifically, this study tried to (i) assess the performance of this sensor for measuring the sediment concentration in post-fire runoff generated during the initial stages of the window of disturbance, when erosion rates are expectedly highest; (ii) evaluate if sensor performance differed for streamflow and for overland flow from erosion plots with contrasting runoff areas (micro-plots vs. slope-scale plots) and, thus, potentially different erosion processes (inter-rill erosion vs. rill/gully erosion); and (iii) determine if sensor performance depended on land cover, parent material and site-specific conditions. This study was envisaged as an important step towards the development of a commercial version of the sensor designed by Bilro et al. (2010).

\section{Study area and sites}

This study was carried out near the hamlet of Ermida in the Sever do Vouga municipality of north-central Portugal (Fig. 1). The area was burnt by a wildfire that took place be-

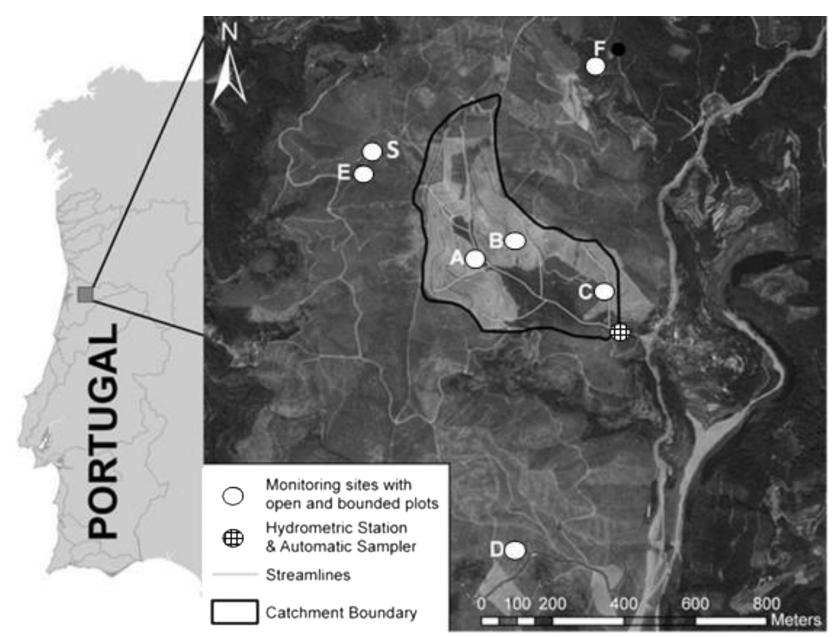

Figure 1. Location of the study area, the experimental catchment and the seven study sites (A: burnt eucalypt plantation on granite; B, D, E and S: burnt eucalypt plantations on schist; C: burnt pine plantation on schist; F: long-unburnt eucalypt plantation on schist).

tween 26 and 28 July 2010 and that affected some 300 ha (DUDF, 2011). By the time of the fire, the area was mainly covered by plantations of eucalypt (Eucalyptus globulus Labill.) but did include some plantations of maritime pine ( $\mathrm{Pi}$ nus pinaster Ait.). The severity of the wildfire (sensu Keely, 2009) was assessed in the field using as indicators ash colour as well as degree of tree crown scorching and of litter layer consumption, following Shakesby and Doerr (2006) and prior studies in the region such as Malvar et al. (2011, 2013). At all six study sites selected within the burnt area (Fig. 1), fire severity was classified as moderate. During the winter of 2010/11, the central part of the study area was bench terraced using a bulldozer, affecting three of the study sites (the terraces are clearly visible in Fig. 1).

The climate of the study area can be classified as humid meso-thermal (Csb, according to the Köppen classification), with moderately dry but extended summers (DRA-Centro, 1998). The parent material in the study area mainly consisted of pre-Ordovician schists but included Hercynian granites at some locations, as is typical for the Hesperic Massif (Ferreira, 1978). The soils were mapped, at a scale of $1: 1000$ 000, as predominantly Humic Cambisols (Cardoso et al., 1971, 1973). However, field descriptions of soil profiles at the various study sites suggested a prevalence of Leptosols (WRB, 2006) (see Machado et al., 2015; Martins et al., 2013). Soil texture of the A horizon was also determined in the field and was slightly coarser for the soils on granite (sandy loam) than for the soils on schist (sandy clay loam). The topsoil was very rich in organic matter, amounting to $20-30 \%$ at $0-2 \mathrm{~cm}$ depth (Machado et al., 2015) and 8-11\% at $0-5 \mathrm{~cm}$ depth (Prats et al., 2014).

Within the burnt area, a total of six study sites were selected to study post-fire runoff and erosion (Fig. 1; Table 1). 
Table 1. General information about the seven study sites as well as the numbers of runoff samples from micro-plots and slope-scale plots analysed from each site and the start and end dates of collecting these samples (in ddmmyy).

\begin{tabular}{|c|c|c|c|c|c|c|c|c|c|c|c|c|}
\hline \multirow[t]{2}{*}{$\begin{array}{l}\text { Site } \\
\text { code }\end{array}$} & \multicolumn{2}{|c|}{ Location } & \multirow[t]{2}{*}{$\begin{array}{l}\text { Wild- } \\
\text { fire }\end{array}$} & \multirow[t]{2}{*}{$\begin{array}{l}\text { Forest } \\
\text { type }\end{array}$} & \multirow[t]{2}{*}{$\begin{array}{l}\text { Parent } \\
\text { material }\end{array}$} & \multirow[t]{2}{*}{ Treatment } & \multicolumn{3}{|c|}{ Micro-plots } & \multicolumn{3}{|c|}{ Slope-scale plots } \\
\hline & Lat. & Lon. & & & & & $\mathrm{N}$ & start & end & $\mathrm{N}$ & start & end \\
\hline \multirow[t]{3}{*}{$\mathrm{S}$} & $40^{\circ} 44^{\prime} 05^{\prime \prime} \mathrm{N}$ & $8^{\circ} 21^{\prime} 18^{\prime \prime} \mathrm{W}$ & burnt & euc. & schist & none & 112 & 260810 & 040112 & 89 & 260810 & 240811 \\
\hline & & & & & & PAM & 78 & 260810 & 070911 & - & 260810 & - \\
\hline & & & & & & mulching & 57 & 260810 & 070911 & 85 & 260810 & 070911 \\
\hline B & $40^{\circ} 43^{\prime} 59^{\prime \prime} \mathrm{N}$ & $8^{\circ} 20^{\prime} 58^{\prime \prime} \mathrm{W}$ & burnt & euc. & schist & none & 33 & 260810 & 230211 & 45 & 260810 & 230211 \\
\hline $\mathrm{D}$ & $40^{\circ} 43^{\prime} 29^{\prime \prime} \mathrm{N}$ & $8^{\circ} 20^{\prime} 57^{\prime \prime} \mathrm{W}$ & burnt & euc. & schist & none & 47 & 260810 & 290411 & 90 & 260810 & 240811 \\
\hline $\mathrm{E}$ & $40^{\circ} 44^{\prime} 04^{\prime \prime} \mathrm{N}$ & $8^{\circ} 21^{\prime} 16^{\prime \prime} \mathrm{W}$ & burnt & euc. & schist & none & 42 & 260810 & 180511 & 70 & 260810 & 240811 \\
\hline A & $40^{\circ} 43^{\prime} 56^{\prime \prime} \mathrm{N}$ & $8^{\circ} 21^{\prime} 3^{\prime \prime} \mathrm{W}$ & burnt & euc. & granite & none & 19 & 260810 & 230211 & 73 & 260810 & 230210 \\
\hline $\mathrm{C}$ & $40^{\circ} 43^{\prime} 54^{\prime \prime} \mathrm{N}$ & $8^{\circ} 20^{\prime} 47^{\prime \prime} \mathrm{W}$ & burnt & pine & schist & none & 28 & 260810 & 230211 & 57 & 260810 & 180511 \\
\hline $\mathrm{F}$ & $40^{\circ} 44^{\prime} 16^{\prime \prime} \mathrm{N}$ & $8^{\circ} 20^{\prime} 45^{\prime \prime} \mathrm{W}$ & unburnt & euc. & schist & none & - & - & - & 56 & 260810 & 010611 \\
\hline
\end{tabular}

They consisted of four eucalypt plantations on schist (sites B, $\mathrm{D}, \mathrm{E}$, and S), one eucalypt plantation on granite (site A) and one pine plantation on schist (site $\mathrm{C}$ ), basically following the incidence of these land cover-parent material combinations in the burnt area. In addition, a long-unburnt eucalypt plantation was selected in the immediate vicinity of the burnt area (site F). Furthermore, one of the catchments within the burnt area was selected for studying the hydrological and erosion response at the catchment scale.

\section{Materials and methods}

\subsection{Experimental set-up and collection of runoff samples}

Five of the six study sites within the burnt area - i.e. except site $\mathrm{S}$ - were divided in three adjacent strips running from the base to the top of the slope (section) (Machado et al., 2015; Martins et al., 2013). In one of these strips, either three bounded micro-plots $\left(0.25-0.30 \mathrm{~m}^{2}\right)$ were installed at the slope's base (sites A, B and C, for being located within the catchments and therefore to minimize disturbance) or two pairs of such micro-plots were installed at the base and halfway up the slope (sites D and E). In another strip, one (un-)bounded slope-scale plot with a width of approximately $2 \mathrm{~m}$ and contributing areas exceeding $50 \mathrm{~m}^{2}$, depending on slope length, was installed. Each slope-scale plot, however, comprised four outlets that were connected to different runoff-collecting tanks. Site $\mathrm{S}$ involved a more elaborate experimental design, as it had been selected to assess the effectiveness of two treatments to reduce soil erosion, i.e. mulching with forest residues and application of a dry granular anionic polyacrylamide (PAM; Prats et al., 2014, 2015). Polyacrylamides have been found to markedly reduce soil losses from agricultural fields and road embankments (BenHur, 2006). Four triplets of the above-mentioned micro-plots were installed from the base to the top of slope $S$ to assess the effectiveness of both treatments. Furthermore, two bounded slope-scale runoff plots of $4 \mathrm{~m}$ width by $20-25 \mathrm{~m}$ length were installed to assess the effectiveness of mulching with forest residues. The unburnt site, on the other hand, involved a simpler experimental design as it was relatively narrow and could only be divided in two strips. Therefore, it was only instrumented with an unbounded slope-scale plot as described above.

The runoff from the micro-plot and the individual outlets of the slope-scale plots was collected in tanks of 30 and 80$500 \mathrm{~L}$, respectively. Runoff volume in the tanks was measured and runoff samples were collected in $1.5 \mathrm{~L}$ bottles, following intensive stirring of the water in the tanks. This was done at 1-2-weekly intervals, depending on rainfall, starting at the end of August 2010 when the site instrumentation had been completed.

The outlet of the experimental catchment was instrumented with a hydrological station comprising two flumes, two water level recorders and an automatic sampler that was triggered by a data logger based on the readings of the two water level recorders.

\subsection{Laboratory analysis of runoff samples}

For this study, a total of 1139 runoff samples were analysed, of which 158 concerned streamflow, and 565 and 416 overland flow at the slope and micro-plot scale, respectively. The distribution of the latter samples over the different sites is given in Table 1. The samples were collected during the first year after the wildfire, as further detailed in Table 1, except for 36 micro-plot samples that were collected at the $\mathrm{S}$ site between the end of October 2011 and early January 2011.

The sediment concentration of these samples was determined in the laboratory using the classic filtration method (APHA, 1998), employing filter paper with a pore diameter of $12-14 \mu \mathrm{m}$ and drying the filters in an oven at $105^{\circ} \mathrm{C}$ for $24 \mathrm{~h}$. Furthermore, the organic matter content of the filtered sediments was determined using the loss-on-ignition method, placing the filters in a muffle for $4 \mathrm{~h}$ at $550^{\circ} \mathrm{C}$.

For each of the runoff samples, the normalized loss of the transmitted light - i.e. the ratio of the loss of light transmit- 

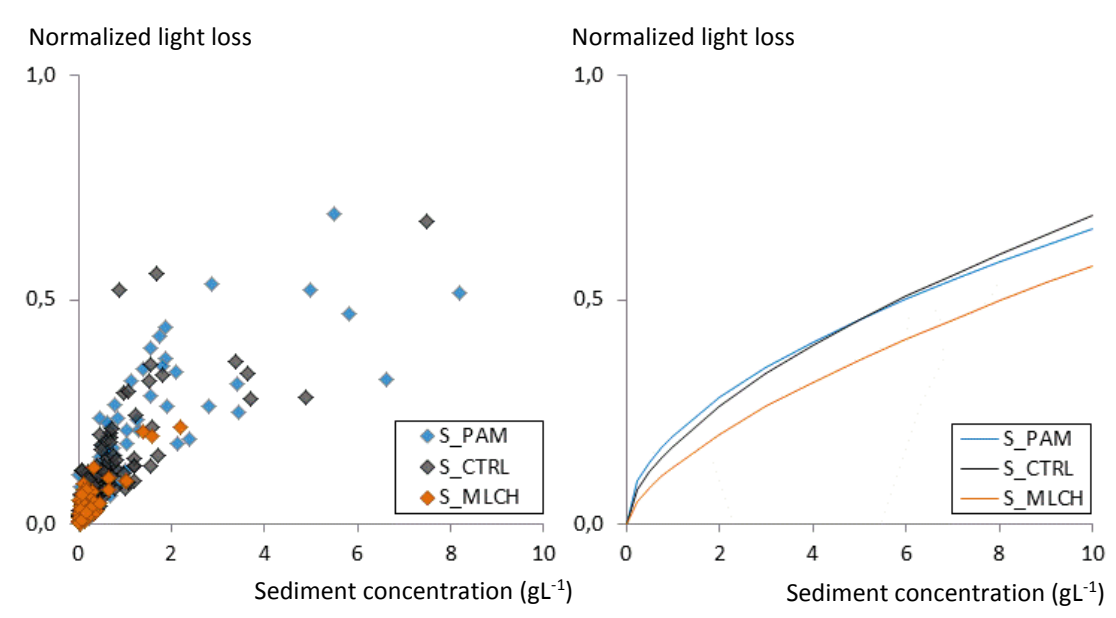

Figure 2. Relationships of sediment concentration with normalized light loss at the micro-plot scale for three treatments at study site $\mathrm{S}$ (left plot) and the corresponding best-fitting power functions (right plot; see Table 2). S_PAM: polyacrylamide; S_CTRL: untreated; S_MLCH: mulching with forest residues.

ted through a runoff sample and transmitted through a reference sample of bi-distilled water - was determined using the POF turbidity sensor presented by Bilro et al. (2010) but with a slightly modified design of the sensor head. To this end, the sensor head was first placed within a plastic recipient with bi-distilled water to measure the reference signal and then within a second recipient with the runoff sample to measure the light loss due to the sediments that were being kept in suspension by means of a magnetic agitator. The measurements were carried out during a period of $1 \mathrm{~min}$, during which the POF sensor performed 120 readings. Following visual inspection for and possible elimination of anomalous readings, the average values of both sets of readings were then used to compute the normalized transmitted light loss.

\subsection{Data analysis}

The sediment concentrations of the runoff samples from the micro-plots and the slope-scale plots were tested for significant differences, at $\alpha=0.05$, between the treatments at site $\mathrm{S}$ as well as between the sites using non-parametric tests. The Kruskal-Wallis test was employed in case of multiple groups and, in case of significant results, followed by multiple pairwise comparisons using post hoc probabilities corrected for the number of comparisons. The Mann-Whitney $U$ test was employed in the case of two groups. All statistical tests were carried out using STATISTICA 9.0 for Windows $\left({ }^{\odot}\right.$ Stat Soft. Inc.).

The relationships of sediment concentrations with normalized light loss were determined using the Origin software $\left({ }^{\odot}\right.$ OriginLab). In a first phase, a range of possible functions (first-to-fourth-order polynomials, exponential, Napierian logarithmic and power) were fitted to the entire sets of micro-plot samples, slope-scale samples and catchment-scale samples. Overall, the third- and fourth-order polynomials and the exponential functions provided the best fits, with identical adjusted $R^{2}$ values $(0.73,0.87$ and 0.85 , respectively). Nonetheless, the power function was preferred for the ensuing results, since the differences in $R^{2}$ values were considered too small $(\leq 0.02)$ to justify the additional one or two unknowns of the other functions.

\section{Results and discussion}

\subsection{Micro-plot scale}

\subsubsection{Within-site differences related to erosion mitigation treatments}

In line with the findings of Prats et al. (2014) regarding specific soil losses, the sample sets of the three treatments differed significantly in sediment concentrations (Table 2). The median sediment concentration of the untreated samples was $35 \%$ lower than that of the PAM samples but almost 3 times higher than that of the mulching samples. The median organic matter contents of all three sample sets were high (52$67 \%$ ), suggesting that charred material was a major component of the sediments exported under all three treatments. These median values closely matched the average values in Prats et al. (2014), attesting to the representativeness of the sample sets included in this study. Furthermore, they agreed well with the figures in Malvar et al. $(2011,2013)$ for sediments eroded during the first 2 years following a fire.

All three sample sets revealed a relationship of increasing normalized light loss with increasing sediment concentration (Fig. 2), as was expected based on the findings with an earlier prototype of the turbidity sensor (Bilro et al., 2010, 2011). The power function provided reasonably good fits of these relationships in all three instances, with adjusted $R^{2}$ values ranging from 0.64 in the case of the untreated samples to 0.72 in the case of the PAM samples (Table 2). Bilro et al. (2011) 
Table 2. Sediment concentrations and corresponding organic matter (OM) contents of the micro-plot scale overland flow samples at the six study sites, and best-fitting power functions between sediment concentration $\left(x\right.$; in $\left.\mathrm{g} \mathrm{L}^{-1}\right)$ with normalized light loss ( $y$ ). Euc.: eucalypt; med.: median; iqr: inter-quartile range; 3rd q: third quartile; max.: maximum; sign: statistically significant differences, at $\alpha=0.05$, are indicated by different roman numbers in the case of the treatments tested at the $\mathrm{S}$ site and by different letters in the case of the other sites.

\begin{tabular}{|c|c|c|c|c|c|c|c|c|c|c|c|c|c|}
\hline \multirow[t]{2}{*}{$\begin{array}{l}\text { Site } \\
\text { code }\end{array}$} & \multirow[t]{2}{*}{$\begin{array}{l}\text { Forest } \\
\text { type }\end{array}$} & \multirow[t]{2}{*}{$\begin{array}{l}\text { Parent } \\
\text { material }\end{array}$} & \multirow[t]{2}{*}{ Treatment } & \multirow[t]{2}{*}{$N$} & \multicolumn{5}{|c|}{$\begin{array}{c}\text { Sediment } \\
\text { concentration } \\
\mathrm{g} \mathrm{L}^{-1}\end{array}$} & \multicolumn{2}{|c|}{$\begin{array}{c}\text { OM } \\
\text { content } \\
\%\end{array}$} & \multirow[t]{2}{*}{$\begin{array}{l}\text { Best-fitting } \\
\text { power function }\end{array}$} & \multirow[t]{2}{*}{$\begin{array}{r}\text { Adjusted } \\
R^{2}\end{array}$} \\
\hline & & & & & med. & iqr & $3 r d q$ & $\max$. & sign & med. & iqr & & \\
\hline \multirow[t]{3}{*}{$S$} & \multirow[t]{3}{*}{ euc. } & \multirow[t]{3}{*}{ schist } & none & 112 & 0.41 & 0.53 & 0.72 & 7.48 & ii & 61 & 24 & $y=0.1735 x^{0.5983}$ & 0.64 \\
\hline & & & PAM & 78 & 0.64 & 1.07 & 1.37 & 8.19 & iii & 52 & 22 & $y=0.1962 x^{0.5247}$ & 0.72 \\
\hline & & & mulching & 57 & 0.14 & 0.20 & 0.27 & 2.19 & $\mathrm{i}$ & 67 & 21 & $y=0.1268 x^{0.6577}$ & 0.69 \\
\hline B & euc. & schist & none & 33 & 0.38 & 0.66 & 0.85 & 3.89 & $\mathrm{~cd}$ & 54 & 12 & $y=0.2965 x^{0.4938}$ & 0.77 \\
\hline $\mathrm{D}$ & euc. & schist & none & 47 & 0.21 & 0.16 & 0.27 & 1.06 & $\mathrm{bc}$ & 55 & 14 & $y=0.2054 x^{0.8090}$ & 0.67 \\
\hline $\mathrm{E}$ & euc. & schist & none & 42 & 0.73 & 1.76 & 2.00 & 6.06 & $\mathrm{~d}$ & 64 & 29 & $y=0.2510 x^{0.5372}$ & 0.76 \\
\hline A & euc. & granite & none & 19 & 0.13 & 0.16 & 0.22 & 0.91 & $a b$ & 58 & 18 & $y=0.2971 x^{0.7912}$ & 0.81 \\
\hline $\mathrm{C}$ & pine & schist & none & 28 & 0.08 & 0.12 & 0.15 & 1.48 & $\mathrm{a}$ & 54 & 12 & $y=0.2808 x^{0.6794}$ & 0.76 \\
\hline
\end{tabular}

found clearly better fits $\left(R^{2}>0.95\right)$ for clay as well as ash particles but the authors used dilution series of artificial samples rather than runoff samples collected in the field.

The curves fitted to the untreated and the PAM samples were very similar, at least within the range of measured sediment concentrations (i.e. $<8.5 \mathrm{~g} \mathrm{~L}^{-1}$ ). It is possible that the somewhat divergent curve of the mulching samples was due to a smaller range of measured sediment concentrations $\left(<2.5 \mathrm{~g} \mathrm{~L}^{-1}\right)$, and because the relationships between sediment concentration and normalized light loss seemed to reveal more spread at higher concentrations.

\subsubsection{Between-site differences related to land cover and parent material}

Conspicuous and, in various instances, significant differences existed between the study sites in the sediment concentration of the micro-plot runoff samples (Table 2). Median sediment concentrations appeared to be influenced by both parent material and forest type, as median values were significantly lower for the pine plantation on schist $\left(0.08 \mathrm{~g} \mathrm{~L}^{-1}\right)$ and for the eucalypt plantation on granite $\left(0.13 \mathrm{~g} \mathrm{~L}^{-1}\right)$ than for the eucalypt plantations on schist $\left(\geq 0.21 \mathrm{~g} \mathrm{~L}^{-1}\right)$. Significant differences, however, also existed among the eucalypt plantations on schist, with the median sediment concentration of the $\mathrm{D}$ site $\left(0.21 \mathrm{~g} \mathrm{~L}^{-1}\right)$ being 3.5 times lower than that of the E site $\left(0.73 \mathrm{~g} \mathrm{~L}^{-1}\right)$. Between-site differences did not seem to be related to fire severity, at least as suggested by the field indicators used in this study (see Sect. 2). The difference in median sediment concentration between the pine plantation on schist and the eucalypt plantation on granite agreed well with the difference in the sites' median specific sediment losses reported by Martins et al. (2013; 0.08 vs. $0.16 \mathrm{~g} \mathrm{~m}^{-2} \mathrm{~mm}^{-1}$ of runoff), once again testifying to the representativeness of the sample sets included in this study.

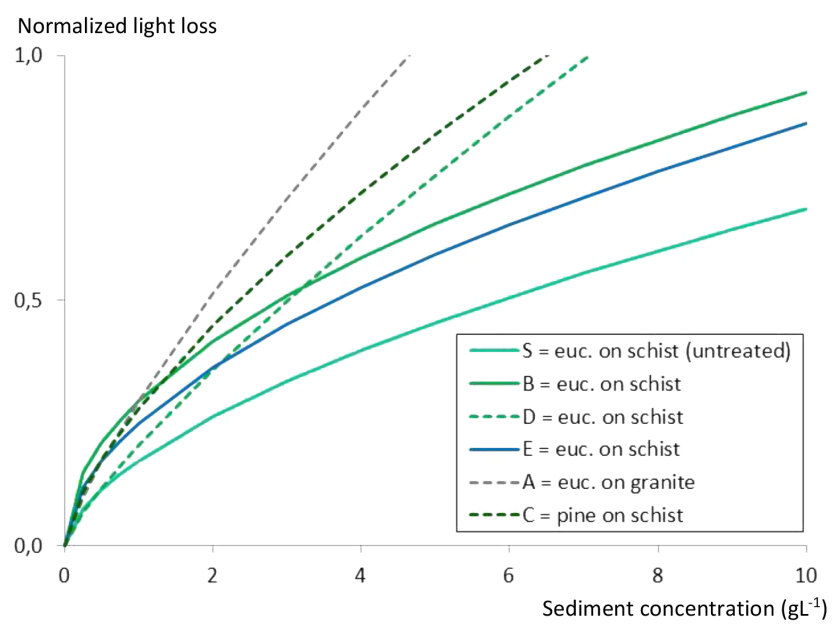

Figure 3. Best-fitting power functions of the relationships of postfire sediment concentration with normalized light loss at the microplot scale for one pine plantation on schist and five eucalypt (euc.) plantations on schist or granite (see Table 2).

The untreated sample sets from all six study sites showed the expected increases in normalized light loss with increasing sediment concentrations. Furthermore, these increases agreed well with power functions, with the adjusted $R^{2}$ values of the fitted curves ranging from 0.64 to 0.81 (Fig. 3; Table 2). The fits were somewhat worse for sites $D$ and $S$ than for the remaining four sites (adjusted $R^{2}$ values: 0.64-0.67 vs. $0.76-0.81$ ) but this difference was apparently unrelated to parent material, forest type, sediment concentrations or their organic matter contents. However, the shape of the fitted curves did seem related to sediment concentrations. The curves were steeper for sites A, C and D than for sites B, E and $\mathrm{S}$, and the former three sites had clearly lower median, third quartile and maximum sediment concentrations than the 


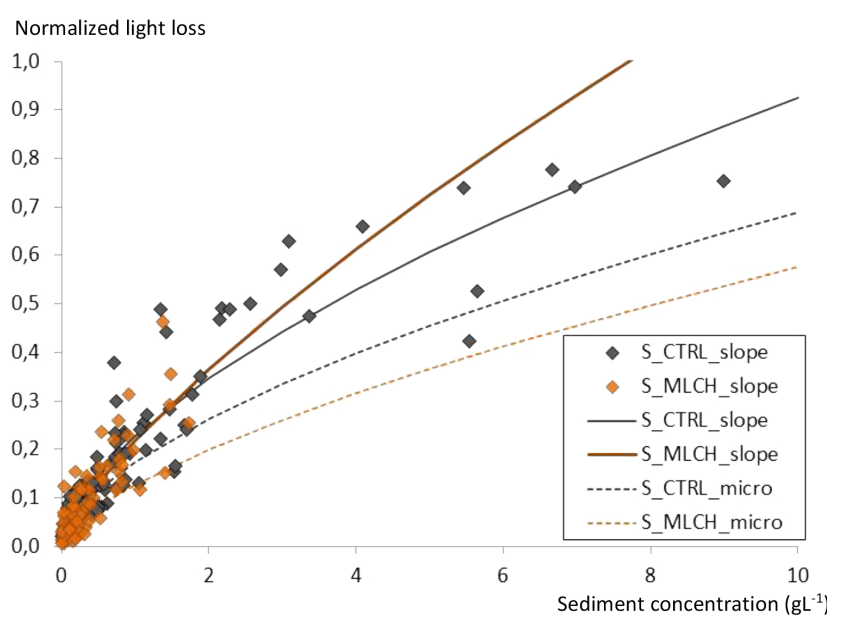

Figure 4. Relationships of post-fire sediment concentration with normalized light loss at the slope scale for two treatments at study site $\mathrm{S}$ (symbols), and best-fitting power functions at the slope as well as micro-plot scale (lines) (see Tables 2 and 3). S_CTRL_slope/micro: untreated; S_MLCH_slope/micro: mulching with forest residues.

latter three sites (e.g. in the case of maximum concentrations, $0.91-1.48$ vs. $3.89-7.48 \mathrm{~g} \mathrm{~L}^{-1}$ ). This contrast could be due to differences in the size of the exported sediment particles, since the sensor's light attenuation was shown to decrease with increasing particle size (Bilro et al., 2011) and since the lower sediment concentrations at sites A, C and D could be explained by overland flow with a lower transport capacity, preferentially exporting smaller particles. Nonetheless, the contrast could also be an artefact from the lower ranges of sediment concentrations measured at sites $\mathrm{A}, \mathrm{C}$ and $\mathrm{D}$, as these ranges only covered the initial, steeper parts of the fitted curves.

\subsection{Slope scale}

\subsubsection{Within-site differences related to erosion mitigation treatment}

Like the micro-plot samples, the slope-scale samples revealed clear and significant differences in sediment concentration between the untreated and mulching samples (Table 3). The median sediment concentration of the untreated samples was more than 3 times higher than that of the mulching samples $\left(0.63\right.$ vs. $\left.0.19 \mathrm{~g} \mathrm{~L}^{-1}\right)$. These differences agreed well with the stronger runoff response of the untreated plot compared to the mulched plot during the first year after a fire (Prats et al., 2015; 58 vs. $30 \mathrm{~mm}$ ).

The slope-scale samples tended to have higher median, third quartile and maximum sediment concentrations than the micro-plot samples of the same treatment (Table 3). The only exception was the maximum sediment concentration of the mulched samples, being $20 \%$ lower in the case of the

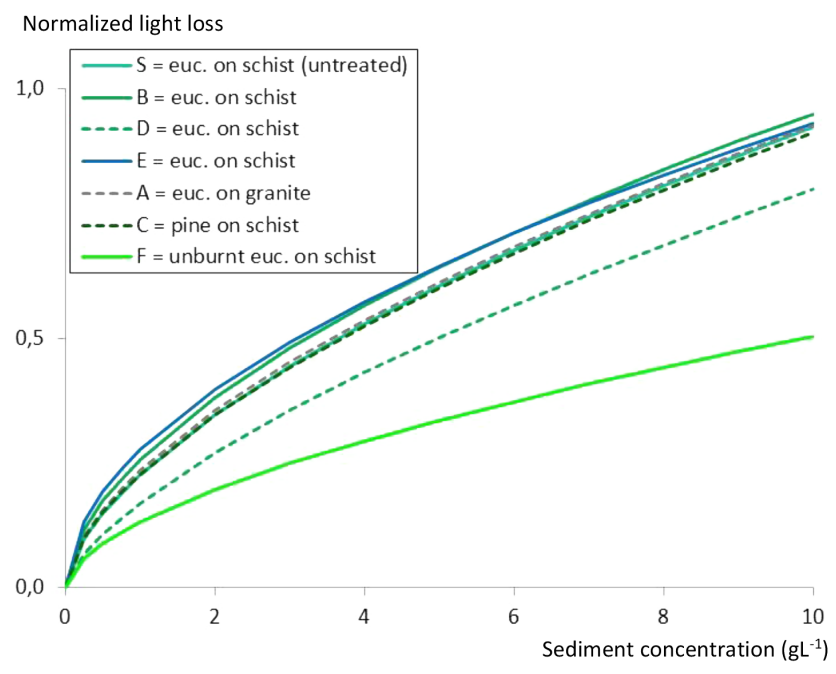

Figure 5. Best-fitting power functions of the relationships of sediment concentration with normalized light loss at the slope scale for one long-unburnt eucalypt (euc.) plantation on schist (F), five recently burnt eucalypt (euc.) plantations on schist or granite (A, B, $\mathrm{D}, \mathrm{E}, \mathrm{S}$ ) and one recently burnt pine plantation on schist (C) (see Table 3).

slope-scale samples than for the micro-plot samples (1.74 vs. $2.19 \mathrm{~g} \mathrm{~L}^{-1}$ ). This tendency in sediment concentrations was opposed to that in overland flow, as Prats et al. (2015) reported roughly 15 times less overland flow at the slope scale than at the micro-plot scale (409-956 vs. 30-58).

The fit of the power function was substantially better for the slope-scale samples than for the micro-plot samples in the case of the untreated plot but basically the same in the case of the mulched plot (Table 3; adjusted $R^{2}$ values: 0.85 vs. 0.64 and 0.71 vs. 0.69 , respectively). In both cases, light loss with increasing sediment concentration was larger for the slope-scale samples than for the micro-plot samples (Fig. 4). Only in the case of the mulching samples, however, was this due to a clearly higher attenuation coefficient ( $0.75 \mathrm{vs.}$ $0.66)$ and, as noted earlier, could be explained by a greater prevalence of smaller particles in the slope-scale samples than in the micro-plot samples (see Bilro et al., 2011), reflecting a reduced transport capacity of the overland flow. This explanation could also account for the lower median organic matter concentration of the slope-scale samples, with the larger charred particles being beyond the runoff's detachment/transport capacity.

\subsubsection{Between-site differences related to fire, land cover and parent material}

The slope-scale samples tended to have higher median, third quartile and maximum sediment concentrations than the micro-plot samples, as was also noted in the previous section. At the same time, however, they revealed similar contrasts between the six burnt study sites, except in the case of 
Table 3. Sediment concentrations and corresponding organic matter (OM) contents of the slope-scale overland flow samples at the seven study sites and best-fitting power functions between sediment concentration $\left(x\right.$; in $\left.\mathrm{g} \mathrm{L}^{-1}\right)$ with normalized light loss $(y)$. Euc.: eucalypt; med.: median; iqr: inter-quartile range; 3rd q: third quartile; max.: maximum; sign: statistically significant differences, at $\alpha=0.05$, are indicated by different roman numbers in the case of the treatments tested at the $\mathrm{S}$ site and by different letters in the case of the other sites.

\begin{tabular}{|c|c|c|c|c|c|c|c|c|c|c|c|c|c|c|}
\hline \multirow[t]{2}{*}{$\begin{array}{l}\text { Site } \\
\text { code }\end{array}$} & \multirow[t]{2}{*}{ Wildfire } & \multirow[t]{2}{*}{$\begin{array}{l}\text { Forest } \\
\text { type }\end{array}$} & \multirow[t]{2}{*}{$\begin{array}{l}\text { Parent } \\
\text { material }\end{array}$} & \multirow[t]{2}{*}{ Treatment } & \multirow[t]{2}{*}{$N$} & \multicolumn{5}{|c|}{$\begin{array}{c}\text { Sediment } \\
\text { concentration } \\
\mathrm{g} \mathrm{L}^{-1}\end{array}$} & \multicolumn{2}{|c|}{$\begin{array}{c}\text { OM } \\
\text { content } \\
\%\end{array}$} & \multirow[t]{2}{*}{$\begin{array}{l}\text { Best-fitting } \\
\text { power function }\end{array}$} & \multirow[t]{2}{*}{$\begin{array}{r}\text { Adjusted } \\
R^{2}\end{array}$} \\
\hline & & & & & & med. & iqr & $3 \mathrm{rd} \mathrm{q}$ & $\max$ & sign & med. & iqr & & \\
\hline \multirow[t]{2}{*}{ S } & \multirow[t]{2}{*}{ burnt } & \multirow[t]{2}{*}{ euc. } & \multirow[t]{2}{*}{ schist } & none & 89 & 0.63 & 1.07 & 1.35 & 8.99 & ii & 64 & 16 & $y=0.2272 x^{0.6095}$ & 0.85 \\
\hline & & & & mulching & 85 & 0.19 & 0.41 & 0.51 & 1.74 & $\mathrm{i}$ & 47 & 23 & $y=0.2163 x^{0.7510}$ & 0.71 \\
\hline B & burnt & euc. & schist & none & 45 & 0.63 & 0.75 & 1.09 & 8.14 & bcd & 58 & 15 & $y=0.2576 x^{0.5670}$ & 0.89 \\
\hline $\mathrm{D}$ & burnt & euc. & schist & none & 90 & 0.29 & 0.84 & 1.00 & 5.86 & $\mathrm{bc}$ & 55 & 14 & $y=0.1704 x^{0.6707}$ & 0.87 \\
\hline E & burnt & euc. & schist & none & 70 & 1.21 & 2.26 & 2.86 & 8.62 & $\mathrm{~cd}$ & 53 & 12 & $y=0.2768 x^{0.5262}$ & 0.83 \\
\hline A & burnt & euc. & granite & none & 73 & 0.69 & 1.12 & 1.39 & 6.59 & bcd & 38 & 12 & $y=0.2356 x^{0.5944}$ & 0.86 \\
\hline $\mathrm{C}$ & burnt & pine & schist & none & 57 & 0.11 & 0.32 & 0.35 & 6.60 & $\mathrm{a}$ & 53 & 19 & $y=0.2281 x^{0.6020}$ & 0.72 \\
\hline $\mathrm{F}$ & unburnt & euc. & schist & none & 56 & 0.05 & 0.14 & 0.15 & 0.74 & $\mathrm{a}$ & 78 & 22 & $y=0.1314 x^{0.5832}$ & 0.52 \\
\hline
\end{tabular}

the eucalypt plantation on granite (Table 3 ). The median sediment concentration was significantly lower for the pine plantation $\left(0.11 \mathrm{~g} \mathrm{~L}^{-1}\right)$ than for the burnt eucalypt plantations (on schist and granite; $\left.\geq 0.29 \mathrm{~g} \mathrm{~L}^{-1}\right)$. The median sediment concentration for the eucalypt plantation on granite lied within the range of values for the other eucalypt plantations, unlike the case of the micro-plot samples. This reflected a comparatively large increase in median sediment concentration from the micro-plot to slope scale. This was in line with the findings of Machado et al. (2015), who reported a marked increase in sediment losses with spatial scale for the eucalypt plantation on granite (from 50 to $140 \mathrm{~g} \mathrm{~m}^{-2}$ ) as opposed to clear decreases for the pine plantation and the eucalypt plantation on schist at site B (from 85 and 200 to 3.5 and $6.1 \mathrm{~g} \mathrm{~m}^{-2}$, respectively).

The sediment concentrations for the unburnt eucalypt plantation were significantly lower than those for the burnt eucalypt plantations. This agreed with the slope-scale sediment losses reported by Machado et al. (2015), being clearly lower for the unburnt than for the burnt eucalypt site on schist $\left(1.2\right.$ vs. $\left.3.5 \mathrm{~g} \mathrm{~m}^{-2}\right)$.

Better fits of the power function were obtained for the slope-scale samples than for the micro-plot samples in the case of five of the six burnt study sites, the pine site being the exception (Table 3). The pine plantation also stood out for its low adjusted $R^{2}$ value (0.72) compared to the other burnt plantations (0.83-0.89). The $R^{2}$ value was similarly low for the mulching samples (0.71) and even considerably lower for the samples from the unburnt eucalypt stand (0.52), suggesting an association between poor fits and reduced sediment concentrations, unlike the case of the micro-plot samples.

The best-fitting curves for the slope-scale samples revealed a greater similarity between the six burnt plantations than those for the micro-plot samples (Fig. 5). Among the burnt plantations, only the $\mathrm{D}$ site stood out but mainly because of a comparatively low base constant rather than a dif-

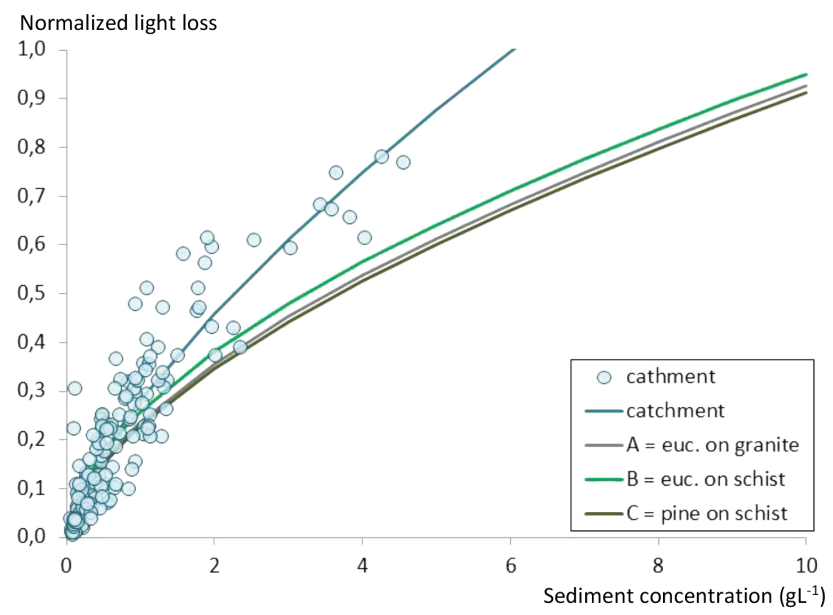

Figure 6. Relationships of sediment concentration with normalized light loss at the catchment scale (symbols), and best-fitting power functions at the catchment as well as slope scale for the eucalypt (euc.) and pine plantations located within the catchment (see Tables 3 and 4).

ferent attenuation coefficient. For the same reason, the curve for the long-unburnt plantation stood out even more from those of the burnt plantations. The discrepancy of these two curves could well be an artefact from the comparatively low sediment concentrations measured at the D and F sites, and because possible differences in particle size due to reduced transport capacity would point to steeper curves, as was the case of the curves fitted to the micro-plot samples of sites A, $\mathrm{C}$ and $\mathrm{D}$ (see Sect. 4.1.2). Unlike in the case of the latter three sites, the curves fitted to the slope-scale samples of sites B and $\mathrm{E}$ agreed particularly well with those fitted to the sites' micro-plot samples. This suggested that wider ranges of measured sediment concentrations provided a more reliable basis 
Table 4. Sediment concentrations and corresponding organic matter (OM) contents of the streamflow samples at the catchment outlet, and best-fitting power function between sediment concentration $\left(x\right.$; in $\left.\mathrm{g} \mathrm{L}^{-1}\right)$ with normalized light loss $(y)$. Med.: median; iqr: inter-quartile range; 3rd q: third quartile; max.: maximum.

\begin{tabular}{|c|c|c|c|c|c|c|c|c|}
\hline \multirow[t]{2}{*}{$N$} & \multicolumn{4}{|c|}{$\begin{array}{c}\text { Sediment } \\
\text { concentration } \\
\mathrm{gL}^{-1}\end{array}$} & \multicolumn{2}{|c|}{$\begin{array}{c}\text { OM } \\
\text { content } \\
\%\end{array}$} & \multirow[t]{2}{*}{$\begin{array}{l}\text { Best-fitting } \\
\text { power function }\end{array}$} & \multirow[t]{2}{*}{$\begin{array}{r}\text { Adjusted } \\
R^{2}\end{array}$} \\
\hline & med. & iqr & $3 \mathrm{rd} \mathrm{q}$ & $\max$ & med. & iqr & & \\
\hline 158 & 0.50 & 0.83 & 1.05 & 4.55 & 22 & 8 & $y=0.2809 x^{0.7071}$ & 0.85 \\
\hline
\end{tabular}

for a consistent relation between turbidity and sediment concentrations over spatial scales as well as across study sites.

\subsection{Catchment scale}

The sediment concentrations of the streamflow samples were more similar to those of slope-scale samples from the B site than from the A and C sites (Table 4). This fitted in well with the fact that the B site represented the dominant land coverparent material combination within the catchment (Table 4). Nonetheless, the maximum value of the streamflow samples was well below the maximum values for all three slopes (4.55 vs. $\left.\geq 6.59 \mathrm{~g} \mathrm{~L}^{-1}\right)$. The median organic matter concentration of the streamflow samples was also comparatively low (22 vs. $\geq 38 \%$ ). Even so, it was substantially higher than the organic matter content of the sediments deposited as bed load within the flume at the catchment outlet (Keizer et al., 2015; $5 \%)$.

The power function provided a good fit to the relationship of increasing normalized light loss with increasing sediment concentration as revealed by the streamflow samples, with an adjusted $R^{2}$ of 0.85 (Table 4 ). The fitted curve, however, differed considerably from the curves fitted to slope-scale samples of the three slopes located within the catchment (Fig. 6). The stronger attenuation coefficient for the streamflow samples (0.71 vs. $0.57-0.60)$ could be due to a prevalence of smaller particles in suspension, especially because of the deposition of sediments in the flume at the catchment outlet as well as in two upstream retention ponds (see Keizer et al., 2015).

\section{Conclusions}

The principal conclusions of this study into the performance of a novel plastic optical fibre (POF) turbidity sensor for measuring soil erosion following a wildfire were the following:

i. the observed sediment concentrations were within the measurement range of the POF sensor, attesting to the suitability of the sensor to be employed during the initial phases of the so-called window of disturbance when erosion losses tend to be highest and exported sediments tend to contain the highest content of - charred - organic matter;

ii. the relationships of sediment concentration with normalized light loss varied markedly with spatial scale and, in particular, between micro-plot and slope-scale samples, on the one hand, and, on the other, catchmentscale samples, suggesting that scale-specific calibration curves are required to guarantee optimal sensor performance;

iii. the slope-scale relationships of sediment concentration with normalized light loss varied clearly less between study sites than the micro-plot-scale relationships, indicating that the need for site-specific calibration curves is greater when sediment concentrations and, thus, erosion rates are comparatively low;

iv. the previous conclusion was also suggested by the comparison of the sediment concentrations with and without an effective erosion mitigation treatment;

v. the POF sensor would allow speeding up considerably the processing of the runoff samples in the laboratory (and, perhaps, even in the field) and, at the same time, would permit an efficient, stratified-sampling approach towards the construction of scale- and/or site-specific calibration curves.

Given the very satisfactory performance of the sensor in this study, further work will include redesigning the sensor and, in particular, its head to make it more robust and more easy to handle, testing the new sensor for continuous monitoring of streamflow turbidity under field conditions, and optimizing data processing algorithms,

Acknowledgements. The present study was carried out in the framework of the projects TRANFIBRA (project no. 23148) and FIRECNUTS (PTDC/AGRCFL/104559/2008), funded by FEDER, through the Agência de Inovação S.A., in the framework of the QREN SI I\&DT program and funded by FCT/MCTES (PIDDAC), with co-funding by FEDER through COMPETE (Programa Operacional Factores de Competitividade; POFC), respectively. Additional financial support was provided by the EU-FP7 project RECARE (grant agreement no. 603498). We further gratefully 
acknowledge the help of various colleagues of the earth surface processes team with field data and sample collection and/or with laboratory analysis of the sediment samples. Finally, we would like to acknowledge the comments and suggestions by the handling editor as well as by the three anonymous reviewers, which helped to improve this manuscript considerably.

Edited by: G. Guzmán

\section{References}

APHA (American Public Health Association): Total suspended solids dried at 105 degrees Celsius method 2540D, in: Standard Methods for the Examination of Water and Waste Water, 20th Edn., Washington, DC, USA, 1998.

Ben-Hur, M.: Using synthetic polymers as soil conditioners to control runoff and soil loss in arid regions - a review, Aust. J. Soil Res., 44, 191-204, 2006.

Bilro, L., Prats, S. A., Pinto, J. L., Keizer, J. J., and Nogueira, N.: Design and performance assessment of a POF based sensor for measuring water turbidity, Meas. Sci. Technol., 21, 107001, doi:10.1088/0957-0233/21/10/107001, 2010.

Bilro, L., Prats, S., Pinto, J. L., Keizer, J. J., and Nogueira, R. N.: Turbidity sensor for determination of concentration, ash presence and particle diameter of sediment suspensions, Proc. Spie., 7753, 775356, doi:10.1117/12.885112, 2011.

Campbell, C., Laycak, D., Hoppes, W., Tran, N. T., and Shib, F.: High concentration suspended sediment measurements using a continuous fiber optic in-stream transmissometer, J. Hydrol., 311, 244-253, 2005.

Cardoso, J. C., Bessa, M. T., and Marado, M. B.: Carta dos solos de Portugal $(1: 1,000,000)$, Serviço de Reconhecimento e de Ordenamento Agrário, Secretaria de Estado da Agricultura, Lisbon, Portugal, 1971.

Cardoso, J. C., Bessa, M. T., and Marado, M. B.: Carta dos solos de Portugal (1:1,000,000), Agronomia Lusitana, 33, 461-602, 1973.

Cerdà, A.: Changes in overland flow and infiltration after a rangeland fire in a Mediterranean shrubland, Hydrol. Process., 12, 1031-1042, 1998.

Downing, J.: Twenty-five years with OBS sensors: The good, the bad, and the ugly, Cont. Shelf. Res., 26, 2299-2318, 2006.

DRA-Centro (Direcção Regional do Ambiente do Centro): Plano de bacia hidrográfica do Rio Vouga, $1^{\circ}$ fase, Análise e diagnóstico da situação de referência, Análise biofísica, Anexos, Lisboa, Portugal, 1998.

DUDF (Direcção de Unidade de Defesa da Floresta): Relatório Anual de Áreas Ardidas e Ocorrências 2010, Autoridade Florestal Nacional, Lisboa, 2011.

Fernández, C., Veja, J. A., Fontúrbel, M. T., Pérez-Gorostiaga, P., Jiménez, E., and Madrigal, J.: Effects of wildfire, salvage logging and slash treatments on soil degradation, Land. Degrad. Dev., 18, 591-607, 2007.

Ferreira, A. de Brum: Planaltos e montanhas do norte da Beira - estudo de geomorfologia, Centro de Estudos Geográficos, Lisbon, Portugal, 1978.

Inbar, M., Tamir, M., and Wittenberg, L.: Runoff and erosion processes after a forest fire in Mount Carmel, a Mediterranean area, Geomorphology, 24, 17-33, 1998.
Keeley, J. E.: Fire intensity, fire severity and burn severity: A brief review and suggested usage, Int. J. Wildland Fire, 18, 116-126, 2009.

Keizer, J. J., Martins, M. A. S., Prats, S. A., Faria, S. R., GonzálezPelayo, O., Machado, A. I., Rial-Rivas, M. E., Santos, L. F., Serpa, D., and Varela, M. E. T.: Within-in flume sediment deposition in a forested catchment following wildfire and post-fire bench terracing, north-central Portugal, Cuadernos de Investigación Geográfica, 41, 149-164, 2015.

Lane, P. N. J., Sheridan, G. J., and Noske, P. J.: Changes in sediment loads and discharge from small mountain catchments following wildfire in south eastern Australia, J. Hydrol., 331, 495510, 2006.

Lavabre, J. and Martin, C.: Impact d'un incendie de forêt sur l'hydrologie et l'érosion hydrique d'un petit bassin versant méditerranéan, Human Impact on Erosion and Sedimentation, Proceedings of Rabat Symposium S6, April 1997, IAHS Publication 245, 39-47, 1997.

Machado, A. I., Serpa, D. R., Ferreira, R. S. V., Rodríguez-Blanco, M. L., Pinto, R., Nunes, M. I., Cerqueira, M. M., and Keizer, J. J.: Cation export by overland flow in a recently burnt forest area in north-central Portugal, Sci. Total Environ., 524-525, 201-212, 2015.

Malvar, M. C., Prats, S. A., Nunes, J. P., and Keizer, J. J.: Post-fire overland flow generation and inter-rill erosion under simulated rainfall in two eucalypt stands in north-central Portugal, Environ. Res., 111, 222-236, 2011.

Malvar, M. C., Martins, M. A., Nunes, J. P., Robichaud, P. R., and Keizer, J. J.: Assessing the role of pre-fire ground preparation operations and soil water repellency in post-fire runoff and interrill erosion by repeated rainfall simulation experiments in Portuguese eucalypt plantations, Catena, 108, 69-83, 2013.

Martins, M. A. S., Machado, A. I., Serpa, D., Prats, S. A., Faria, S. R., Varela, M. E. T., Gonzalez-Pelayo, O., and Keizer, J. J.: Runoff and inter-rill erosion in a Maritime Pine and a eucalypt plantation following wildfire and terracing in north-central Portugal, J. Hydrol. Hydromech., 61, 261-269, 2013.

Mayor, A. G., Bautista, S., Llovet, J., and Bellot, J.: Post-fire hydrological and erosional responses of a Mediterranean landscape: seven years of catchment-scale dynamics, Catena., 71, 68-75, 2007.

Moody, J. A., Shakesby, R. A., Robichaud, P. R., Cannon, S. H., and Martin, D. A.: Current research issues related to post-wildfire runoff and erosion processes, Earth-Sci. Rev., 122, 10-37, 2013.

Omar, A. F. B. and MatJafri, M. Z. B.: Turbidimeter design and analysis: a review on optical fiber sensors for the measurement of water turbidity, Sensing, 9, 8311-8335, 2009.

Postolache, O. A., Silva Girao, P. M. B., Dias Pereira, J. M., and Ramos, H. M.: Multibeam optical system and neural processing for turbidity measurement, IEEE Sens. J., 7, 677-684, 2007.

Prats, S. A., Martins, M. A. S., Malvar, M. C., Ben-Hur, M., and Keizer, J. J.: Polyacrylamide application versus forest residue mulching for reducing post-fire runoff and soil erosion, Sci. Total Environ., 468-469, 464-474, 2014.

Prats, S. A., Wagenbrenner, J. W., Martins, M. A. S., Malvar, M. C., and Keizer, J. J.: Hydrological implications of postfire mulching across two spatial scales, Land Degrad. Dev., doi:10.1002/ldr.2422, online first, 2015. 
Robichaud, P. R., Elliot, W. J., Pierson, F. B., Hall, D. E., and Moffet, C. A.: Predicting postfire erosion and mitigation effectiveness with a web-based probabilistic erosion model, Catena, 71, 229-241, 2007.

Ruhl, C. A., Schoellhamer, D. H., Stumpf, R. P., and Lindsay, C. L.: Combined use of remote sensing and continuous monitoring to analyse the variability of suspended-sediment concentrations in San Francisco Bay, California, Estuar. Coast. Shelf S., 53, 801812, 2001.

Shakesby, R.: Post-wildfire soil erosion in the Mediterranean: review and future 730 research directions, Earth-Sci. Rev., 105, 71-100, 2011.

Shakesby, R. A. and Doerr, S. H.: Wildfire as a hydrological and geomorphological agent, Earth-Sci. Rev., 74, 269-307, 2006.
Thomas, A. D., Walsh, R. P. D., and Shakesby, R. A.: Nutrient losses in eroded sediment after fire in eucalyptus and pine forests in the wet Mediterranean environment of northern Portugal, Catena, 36, 283-302, 1999.

WRB (World reference base for soil resources): World Soil Resources Reports, 103, FAO, Rome, 2006.

Yeo, T. L., Sun, T., and Grattan, K. T. V.: Fibre-optic sensor technologies for humidity and moisture measurement, Sensor Actuat. A-Phys., 144, 280-295, 2008.

Ziemann, O., Krauser, J., Zamzow, P. E., and Daum, W.: POF Handbook - Optical Short Range Transmission Systems, 2nd Edn., Springer-Verlag, Berlin Heidelberg, 2008. 